\title{
Grazing Effects on Floristic Composition and Above Ground Plant Biomass of the Grasslands in the Northeastern Mongolian Steppes
}

\author{
Hayashi, Ichiroku'*, Kiyokazu Kawada', Mayu Kurosu ${ }^{3}$, Amgaa Batjargal ${ }^{4}$, \\ Tsagaanbandi Tsundeekhuu ${ }^{5}$ and Toru Nakamura ${ }^{4}$ \\ 173-5 Kosato, Ueda, Nagano, Japan 386-0005 \\ ${ }^{2}$ National Institute for Agro-Environmental Sciences, 313 Kannon-dai, Tsukuba Ibaraki, Japan \\ ${ }^{3}$ Doctorial Program of Life and Environmental Sciences, University of Tsukuba, Tsukuba, Japan \\ "Institute of Geoecology, Mongolian Academy of Science, Buruun Selbe 15, Ulaanbaatar, Mongolia \\ ${ }^{5}$ Department of Botany and Plant Physiology, Faculty of Biology, National University of Mongolia \\ P.O. Box 767, Ulaanbaatar, Mongolia
}

\begin{abstract}
We describe plant biomass in the grasslands of the Mongolian steppe obtained using a quadrat sampling technique. Four sites were studied in the northeastern Mongolia located between $47^{\circ} 12^{\prime} \mathrm{N}$ and $47^{\circ} 40^{\prime} \mathrm{N}$ and $102^{\circ} 22^{\prime} \mathrm{E}$ and $112^{\circ} 24^{\prime} \mathrm{E}$, which were typical grasslands of the steppe. Biomass, carbon and nitrogen content were determined for the plants collected from the grazed and ungarazed stands. With the measurements above, we expect to obtain information on grazing effects on the grasslands and carbon sequestration of the grassland from the air. In order to estimate the biomass without destroying the stands, we derived an equation to describe the relationship between plant biomass and v-value using plant height and species coverage within the stand. Estimated plant biomass in the ungrazed and grazed stands ranged between $108.0 \mathrm{~g} \mathrm{~m}^{-2}$ and $13.4 \mathrm{~g} \mathrm{~m}^{-2}$ and between $97.5 \mathrm{~g} \mathrm{~m}^{-2}$ and $14.1 \mathrm{~g} \mathrm{~m}^{-2}$ in late June 2005, respectively. Litter in the ungrazed and grazed stands ranged from $330.3 \mathrm{~g} \mathrm{~m}^{-2}$ to $78.4 \mathrm{~g} \mathrm{~m}^{-2}$ and from $188.0 \mathrm{~g} \mathrm{~m}^{-2}$ to $20.3 \mathrm{~g} \mathrm{~m}^{-2}$, similarly. Average carbon and nitrogen contents in plants and in litter were $43.0 \%$ and $1.9 \%$ and $33.7 \%$ and $1.4 \%$, respectively. In study sites at Baganuur, the carbon and nitrogen content of plant materials (plant plus litter) was $118.4 \mathrm{~g} \mathrm{~m}^{-2}$ and $4.7 \mathrm{~g} \mathrm{~m}^{-2}$ on 30 June 2005.
\end{abstract}

Key words: Mongolian steppes, Nitrogen and carbon contents, Plant biomass

\section{INTRODUCTION}

The article aims to describe effects of grazing on floristic composition and above-ground plant biomass in a grassland in the northeastern Mongolia.

The Mongolian steppes occupy approximately $150,000 \mathrm{~km}^{2}$ of the Eurasian grasslands. The grassland ecosystem is characterized by extremely low winter temperatures, an arid climate, and as having human impacts such as grazing pressure. Recently, the grassland ecosystems of Mongolia have come under increased threat of degradation due to overgrazing by livestock (Gunin et al. 1999, Wuyunna et al. 2004, Hiblig and Opp 2005, Sasaki et al. 2005, Xie et al. 2007). The Mongolian grasslands are not only having an important in the raising livestock, but also for atmospheric carbon sequestration. Research regarding the proper use of grasslands is therefore important if the sustainability of the grasslands is to be increased.
In order to determine the amount of plant biomass, carbon and nitrogen contained within the Mongolian grassland, we measured the mass of plants in the stands of vegetation using the harvesting method. We also recorded the floristic composition using a quadrat sampling technique in the grazed and ungrazed stands. With the measurements above, we expect to obtain information on grazing effects on the grassland and carbon sequestration of the grassland from the air. Using information on floristic composition of the stand we are able to recognize the extent of regions applicable to a result of biomass study in a selected site. That is to say, the plant biomasses in the stands having similar floristic composition are similar in amount of biomass in each other (Cheng and Nakamura 2006, 2007).

Plant biomass production in a region has been determined using the following four methods: 1. Estimation by meteorological factors, such as temperature, precipitation and solar radiation, 2. Measurement by the eddy covariance technique (Kato et al. 2004), 3. Measurement by the remote sensing technique (Kawamura et al. 2003)

\footnotetext{
* Corresponding author; Phone: +81-268-24-4344, e-mail: ihayashi@coral.ocn.ne.jp
} 
and 4. Direct measurement of plants for each species within the stands (ecological measurement). In the present study, we employed the fourth technique for determination of biomass.

\section{STUDY SITES AND METHODS}

\section{Study Sites}

Study sites were selected after conducting surveys of large areas. The study sites were Hotont in Arkhangai Province $\left(47^{\circ} 23^{\prime} \mathrm{N}, 102^{\circ}\right.$ $\left.22^{\prime} \mathrm{E}\right)$, Baganuur in Ulaanbaatar Province $\left(47^{\circ} 47^{\prime} \mathrm{N}, 108^{\circ} 29^{\prime} \mathrm{E}\right)$, Kherlenbayan-Ulaan $(\mathrm{KBU})$ in Khentei Province $\left(47^{\circ} 12^{\prime} \mathrm{N}, 108^{\circ} 41^{\prime} \mathrm{E}\right)$ and Tumentsogt in Sukhbaatar province $\left(47^{\circ} 40^{\prime} \mathrm{N}, 112^{\circ} 24^{\prime} \mathrm{E}\right)$, which were typical steppe. These sites were located between $921 \mathrm{~m}$ and $1,580 \mathrm{~m}$ altitude on a gently rolling plain. The stand of KBU had a slant landform in small scale. We considered the KBU site to be a slant landform in the study area. The soil was chestnut soil and the vegetation of the area was typical of the steppe environment, being dominated by the genus of Stipa. The grasslands have traditionally been used for grazing. The study was conducted from 29 June to 6 July 2005. The mean growth period of the vegetation was 64 days $(60 \sim 67$ days), with plant growth considered to begin on 1 May.

According to the records of Institute of Meteorology and Hydrology (2005), the mean annual temperature and precipitation are as follows: $2.3^{\circ} \mathrm{C}$ and $208.9 \mathrm{~mm}$ in Baganuur, $0.7^{\circ} \mathrm{C}$ and $181.3 \mathrm{~mm}$ in $\mathrm{KBU}, 1.9^{\circ} \mathrm{C}$ and $280 \mathrm{~mm}$ in Tumentsogt, and $1.9^{\circ} \mathrm{C}$ and 185.9 $\mathrm{mm}$ in Hotont. The precipitation occurs primarily in the summer season.

Quadrat sampling was conducted in ungrazed stands enclosed by fences and grazed stands. The constructing dates and scale of the ungrazed stands were $50 \mathrm{~m} \times 50 \mathrm{~m}$ in 2003 in Baganuur, $50 \mathrm{~m} \times$ $50 \mathrm{~m}$ in 2002 in $\mathrm{KBU}$, and $100 \mathrm{~m} \times 100 \mathrm{~m}$ in 1999 in Tumentsogt. The season of construction the experimental stands was spring for each year. In Hotont, studies were conducted in grazed stands only.

\section{Methods}

We measured plant height and species coverage at five points within a $1-\mathrm{m}^{2}$ quadrat, in quadrats at $10 \mathrm{~m}$ intervals along two transects set $10 \mathrm{~m}$ apart. After recording the species in the quadrat, we measured the height of the highest plant and the coverage of each species using the Penfound-Howard method modified by Numata (1987). Numata's summed dominance ratio (SDR) was determined from the measures of plant height, coverage and frequency of occurrence. The aboveground plant biomass of the stands was determined by clipping the individual plant at the base and then assigning their species. Any litter in the stand, including standing litter, was collected.
Aboveground plant biomass for each species was then weighed after drying for 24 hours in an oven at $80^{\circ} \mathrm{C}$.

In order to estimate plant biomass in stand without the need for destructive sampling, we determined the $v$-value as proposed by Kawada et al. (2006). The $v$-value is a product of plant height $(\mathrm{cm})$ and coverage of population of the species, which is evaluated using the criteria of Penfound-Howard-Numata (Numata 1987). The unit of measurement for the $v$-value is $\mathrm{cm}^{3}$. To calculate in the same unit, the coverage of population of the species mentioned above was converted as follows: $4: 8,800 \mathrm{~cm}^{2}, 3: 6,300 \mathrm{~cm}^{2}, 2: 3,800 \mathrm{~cm}^{2}$, 1: $1,600 \mathrm{~cm}^{2}, 0.2: 300 \mathrm{~cm}^{2}$ and $0.04: 50 \mathrm{~cm}^{2}$. We derived an equation of the relationship between the $v$-value and plant biomass. Using the equation, we are able to estimate the plant biomass of the stand without destructive sampling. In this study, we calculated the average biomass of five stands for each study site. The Student's t-test was used to calculate the correlation coefficient of the measured biomass values and those estimated using the equation. The difference between plant biomass in the grazed and ungrazed stands was then assessed using the Mann-Whitney $U$ test.

In order to obtain preliminary information on weight ratio of above and below ground biomasses, we collected plants of Artemisia scoparia including the below ground parts of plant.

The nitrogen and carbon contents were determined using a Shimazu C-N analyzer. Carbon and nitrogen measurements were conducted in triplicate.

\section{RESULTS}

\section{Dry : Fresh Weight Ratio of Plant Materials}

The ratio of dry and fresh weights of the plants recorded at each study site are shown in Table 1 . The mean ratio of dry weight to fresh weight of plants was 0.48 . The figures varied among species, ranging from 0.81 in Caragana stenophylla to 0.14 in Schizonepeta 0.48 steppe plants in Inner Mongolia was 0.43 . The fresh weight, dry weight and water content of the plant biomass from the stands are shown in Table 2. For the ungrazed stand in Baganuur, the fresh weight, dry weight and water content of plant biomass was $250.3 \mathrm{~g} \mathrm{~m}^{-2}, 133.8 \mathrm{~g} \mathrm{~m}^{-2}$ and $136.5 \mathrm{~g} \mathrm{~m}^{-2}$, respectively. In this region, circa 1.4 tons of water per hectare was available for livestock by grazing the plants. In the grazed stands, fresh and dry biomasses were $167.5 \mathrm{~g} \mathrm{~m}^{-2}$ and $73.7 \mathrm{~g} \mathrm{~m}^{-2}$, respectively. The water content in the stands studied ranged between $41.5 \%$ and $56.0 \%$.

\section{Relationship between Aboveground Biomass and v-values}

The spatial distribution of plant biomass in grasslands is not homogenous. Consequently, in order to accurately estimate grassland biomass, it is necessary to harvest plants from numerous points 
Table 1. Ratio of dry weight to fresh weight of plant materials in the Mongolian steppes

\begin{tabular}{|c|c|c|c|}
\hline Species & $\begin{array}{c}\text { Dry } \\
\text { weight } \\
\text { /fresh } \\
\text { weight }\end{array}$ & Species & $\begin{array}{c}\text { Dry } \\
\text { weight } \\
\text { /fresh } \\
\text { weight }\end{array}$ \\
\hline Achnatherum sibiricum $\left.{ }^{5}\right)$ & 0.63 & Haplophyllum dahuricum ${ }^{1)}$ & 0.35 \\
\hline Achnatherum sibiricum ${ }^{6}$ & 0.55 & Haplophyllum dahuricum ${ }^{2)}$ & 0.39 \\
\hline Agropyron cristatum $^{1)}$ & 0.43 & Haplophyllum dahuricum ${ }^{3)}$ & 0.69 \\
\hline Agropyron cristatum $^{2)}$ & 0.48 & Haplophyllum dahuricum ${ }^{4)}$ & 0.60 \\
\hline Agropyron cristatum ${ }^{3)}$ & 0.64 & Haplophyllum dahuricum ${ }^{6}$ & 0.55 \\
\hline Agropyron cristatum $^{5)}$ & 0.58 & Iris flavissima ${ }^{1\}}$ & 0.30 \\
\hline 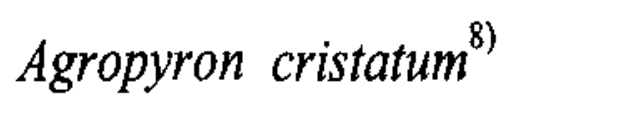 & 0.53 & Iris flavissima ${ }^{2)}$ & 0.16 \\
\hline Allium anisopodium ${ }^{3)}$ & 0.35 & Iris flavissima ${ }^{4)}$ & 0.26 \\
\hline Allium anisopodium ${ }^{4)}$ & 0.29 & Iris flavissima $a^{7}$ & 0.83 \\
\hline Allium bidentatum ${ }^{1)}$ & 0.28 & Koeleria cristata & 0.40 \\
\hline Allium bidentatum ${ }^{2)}$ & 0.29 & Koeleria cristata ${ }^{2)}$ & 0.43 \\
\hline Allium bidentatum ${ }^{7)}$ & 0.29 & Koeleria cristata & 0.77 \\
\hline Allium bidentatum ${ }^{8}$ & 0.30 & Koeleria cristata $^{4)}$ & 0.64 \\
\hline Alyssum lenense $e^{1)}$ & 0.42 & Koeleria cristata $^{5}$ & 0.65 \\
\hline Alyssum lenense $e^{2)}$ & 0.56 & Koeleria cristata $^{6)}$ & 0.74 \\
\hline Arenaria capillaris ${ }^{\mathrm{l}}$ & 0.52 & Koeleria cristata $^{8)}$ & 0.66 \\
\hline Arenaria capillaris $^{8}$ & 0.58 & Leymus chinensis ${ }^{\mathrm{l}}$ & 0.42 \\
\hline Artemisia frigida ${ }^{5)}$ & 0.47 & Leymus chinensis ${ }^{2}$ & 0.45 \\
\hline Artemisia frigida $^{6}$ & 0.70 & Leymus chinensis ${ }^{5}$ & 0.54 \\
\hline Artemisia frigida ${ }^{7)}$ & 0.46 & Leymus chinensis ${ }^{6)}$ & 0.59 \\
\hline Artemisia frigida ${ }^{8)}$ & 0.51 & Leymus chinensis ${ }^{7)}$ & 0.49 \\
\hline Artemisia glauca ${ }^{7}$ & 0.37 & Leymus chinensis ${ }^{8)}$ & 0.51 \\
\hline Artemisia glauca ${ }^{8)}$ & 0.35 & Medicago falcata ${ }^{1)}$ & 0.30 \\
\hline Asparagus dahuricus ${ }^{3)}$ & 0.58 & Medicago falcata ${ }^{2)}$ & 0.31 \\
\hline Asparagus dahuricus ${ }^{4)}$ & 0.43 & Poa botryoides ${ }^{5)}$ & 0.54 \\
\hline Bupleurum scorzonerifolia ${ }^{1)}$ & 0.42 & Polygonum divaricatum ${ }^{5)}$ & 0.22 \\
\hline Caragana microphylla & 0.75 & Potentilla acaulis ${ }^{2}$ & 0.29 \\
\hline Caragana microphylla & 0.54 & Potentilla bifurca ${ }^{8)}$ & 0.36 \\
\hline Caragana microphylla ${ }^{6}$ & 0.66 & Schizonepeta multifida ${ }^{5)}$ & 0.14 \\
\hline Caragana stenophylla & 0.50 & Serratula centauroides ${ }^{1)}$ & 0.29 \\
\hline Caragana stenophylla & 0.45 & Serratula centauroides ${ }^{2)}$ & 0.05 \\
\hline Caragana stenophylla) & 0.81 & Serratula centauroides ${ }^{5)}$ & 0.35 \\
\hline Carex duriuscula & 0.47 & Serratula centauroides ${ }^{6)}$ & 0.77 \\
\hline Carex duriuscula ${ }^{2)}$ & 0.45 & Sibbaldia adpressa ${ }^{1)}$ & 0.52 \\
\hline Carex duriuscula ${ }^{7)}$ & 0.67 & Sibbaldia adpressa $a^{7)}$ & 0.60 \\
\hline Carex duriuscula & 0.56 & Sibbaldia adpressa) & 0.54 \\
\hline
\end{tabular}

Table 1. Continued

\begin{tabular}{|c|c|c|c|}
\hline Species & $\begin{array}{c}\text { Dry } \\
\text { weight } \\
\text { /fresh } \\
\text { weight }\end{array}$ & Species & $\begin{array}{c}\text { Dry } \\
\text { weight } \\
\text { /fresh } \\
\text { weight }\end{array}$ \\
\hline Carex korshinskyi & 0.76 & Stipa baicalensis ${ }^{1)}$ & 0.49 \\
\hline Carex korshinskyi & 0.76 & Stipa baicalensis ${ }^{2)}$ & 0.36 \\
\hline Caryopteris mongolica ${ }^{3)}$ & 0.53 & Stipa grandis ${ }^{5}$ & 0.59 \\
\hline Caryopteris mongolica ${ }^{4)}$ & 0.55 & Stipa grandis $^{6}$ & 0.58 \\
\hline Cleistogenes squarrosa) & 0.61 & Stipa krylovii & 0.71 \\
\hline Cleistogenes squarrosa ${ }^{6}$ & 0.27 & Stipa krylovii ${ }^{4)}$ & 0.75 \\
\hline Cleistogenes squarrosa) & 0.46 & Stipa krylovii ${ }^{7}$ & 0.61 \\
\hline Convolvulus ammanni ${ }^{3)}$ & 0.66 & Stipa krylovii ${ }^{8)}$ & 0.52 \\
\hline Cymbaria dahurica $^{2)}$ & 0.23 & Taraxacum sp. ${ }^{7)}$ & 0.31 \\
\hline Cymbaria dahurica ${ }^{7)}$ & 0.45 & Thalictrum squarrosum ${ }^{5)}$ & 0.40 \\
\hline Cymbaria dahurica $^{8)}$ & 0.37 & Tharictrum minus ${ }^{2)}$ & 0.55 \\
\hline Echinops gmelinii ${ }^{2)}$ & 0.27 & Thermopsis lanceolata ${ }^{8)}$ & 0.34 \\
\hline Ephedra sinica ${ }^{5}$ & 0.41 & Tragopogon trachycarpus ${ }^{1)}$ & 0.19 \\
\hline Filifolium sibiricum $^{1)}$ & 0.25 & Veronica incana ${ }^{1)}$ & 0.53 \\
\hline Galium verum $^{8)}$ & 0.65 & Veronica incana ${ }^{2)}$ & 0.38 \\
\hline Mean ratio & & & 0.48 \\
\hline
\end{tabular}

${ }^{1)}$ Baganuur Ungrazed, ${ }^{2}$ Baganuur Grazed, ${ }^{3)} \mathrm{KBU}$ Ungrazed, ${ }^{4} \mathrm{KBU}$ Grazed, ${ }^{5)}$ Tumentsogt Ungrazed, ${ }^{6}$ Tumentsogt Grazed, ${ }^{7)}$ Hotont-1, ${ }^{8)}$ Hotont-2.

Table 2. Fresh and dry weight of plant biomass in the stands in the Mongolian steppes

\begin{tabular}{lcccc}
\hline \hline Sites & $\begin{array}{c}\text { Fresh weight } \\
\left(\mathrm{g} \mathrm{m}^{-2}\right)\end{array}$ & $\begin{array}{c}\text { Dry weight } \\
\left(\mathrm{g} \mathrm{m}^{-2}\right)\end{array}$ & $\begin{array}{c}\text { Water } \\
\text { content }(\%)\end{array}$ & $\begin{array}{c}\text { Water content } \\
\left(\mathrm{g} \mathrm{m}^{-2}\right)\end{array}$ \\
\hline Baganuur & & & & \\
Ungrazed & 250.3 & 113.8 & 54.5 & 136.5 \\
Grazed & 167.5 & 73.7 & 56.0 & 93.8 \\
\hline KBU & & & & \\
Ungrazed & 51.8 & 29.4 & 43.4 & 22.5 \\
Grazed & 24.1 & 14.1 & 41.5 & 10.0 \\
\hline Tumentsogt & & & & \\
Ungrazed & 170.3 & 83.5 & 51.0 & 86.8 \\
Grazed & 83.7 & 48.2 & 42.4 & 35.5 \\
\hline Hotont & & & & \\
Grazed(1) & 266.4 & 126.8 & 52.4 & 139.6 \\
Grazed(2) & 356.1 & 160.0 & 55.1 & 196.1 \\
\hline
\end{tabular}


within the study site. However, since the clipping and identification of plant specimens in the field is both time and labor intensive, the period over which plant biomass can be harvested is limited. In order to estimate plant biomass without destructive sampling, we derived an equation to describe the reiationship between plant biomass and the $v$-value using both plant height and coverage of species population in a stand. Using the ungrazed stand at Baganuur as an example, the relationship between $v$-values $\left(v: 100 \times \mathrm{cm}^{3}\right)$ and plant biomass (w: g) for each species is given in Fig. 1. The equation describing the relationship is given as:

$$
\mathrm{w}=4.8^{*} \ln (v)-7.9 \quad R^{2}=0.89
$$

Table 3 shows the measured and estimated plant biomass values and the $v$-value for each species in the ungrazed stands of the Baganuur study site.

The $v$-value of the stands was $1.9725 \times 10^{5} \mathrm{~cm}^{3}$ in the ungrazed stand. Measured and estimated aboveground plant biomass were $113.8 \mathrm{~g} \mathrm{~m}^{-2}$ and $117.3 \mathrm{~g} \mathrm{~m}^{-2}$. The equations of the relationship in Baganuule, KBU, Tumentsogt and Hotont are shown in Table 4. Using these equations, we estimated plant biomass at the study sites. These equations were shown to be significant by the Student's $t$-test.

The relationships given in Table 4 are approximated with the functions of linear in $\mathrm{KBU}$ and Tumentsogt, the logarithmic in Baganuur, KBU and Tumentsogt and the power in Baganuur. The cause of difference among the stands remains to be elucidated in future though it is speculated that the difference suggests the difference of stand structure for each site.

\section{Testing the Applicability of the Equations}

In order to test the applicability of the equations, we compared the measured and estimated values of plant biomass in the stands studied (Table 5). For Baganuur, the measured and estimated values

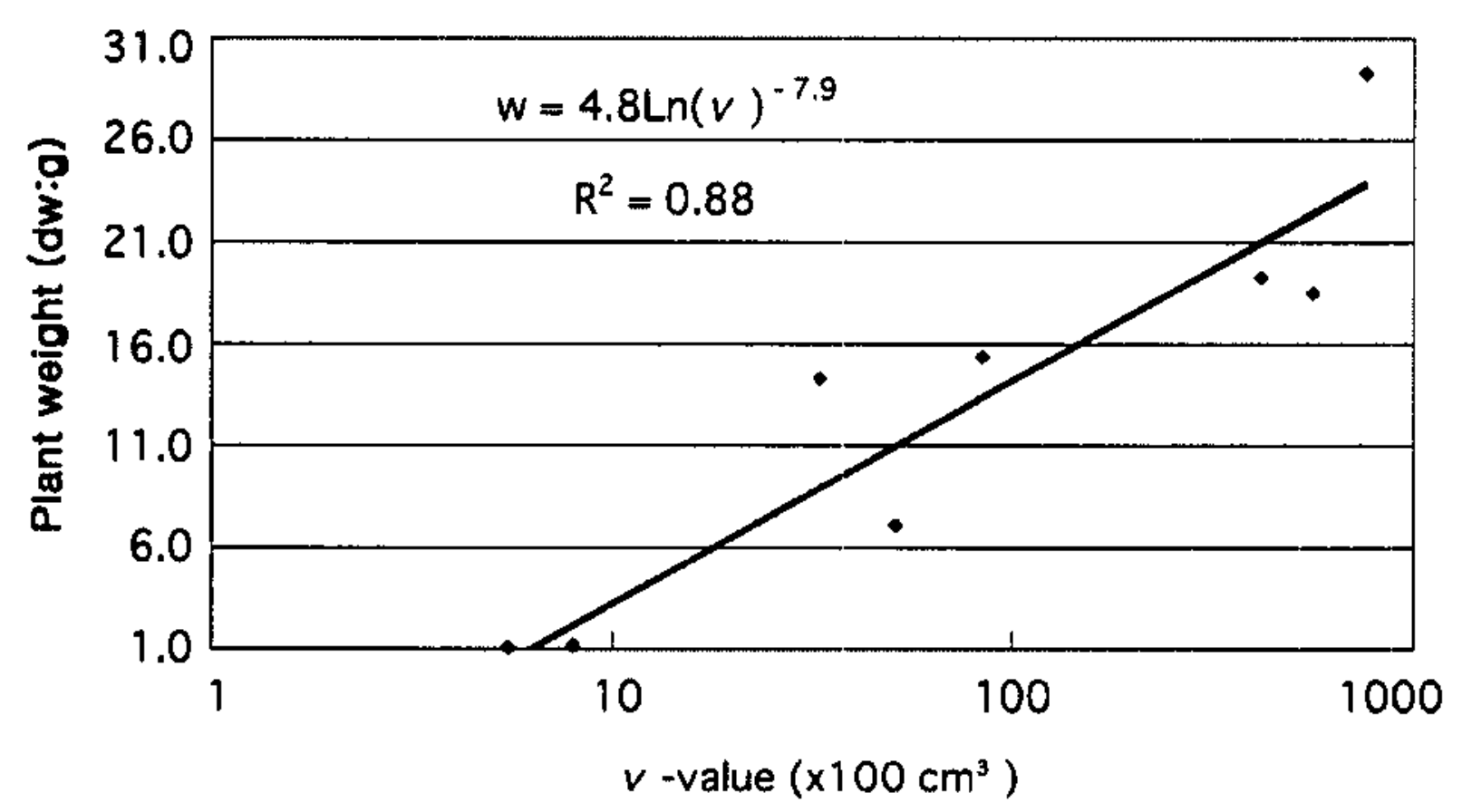

Fig. 1. Relationship between the $v$-value and plant dry weight in the ungrazed stand in Baganuur. were $113.8 \mathrm{~g} \mathrm{~m}^{-2}$ and $108.0 \mathrm{~g} \mathrm{~m}^{-2}$ in the ungrazed stand and 97.5 $\mathrm{g} \mathrm{m}^{-2}$ and $73.7 \mathrm{~g} \mathrm{~m}^{-2}$ in the grazed stand, giving a difference of $5 \%$ and $32 \%$. The differences between the measured and estimated values were within $16 \%$ in grazed and $21 \%$ in ungrazed at Tumensogt and $19 \%$ in grazed stand in Hotont, respectively.

Variance of Plant Biomass and Spatial Distribution in Grasslands

We examined the variance among estimated plant biomass at the Baganuur site in Table 6. In the ungrazed stand, plant biomass from

Table 3. Measured and estimated plant biomasses and $v$-value of the ungrazed stand in Baganuur

\begin{tabular}{|c|c|c|c|}
\hline \multirow[b]{2}{*}{ Species } & \multicolumn{3}{|c|}{ Plant biomass $\left(\mathrm{g} \mathrm{m}^{-2}\right)$} \\
\hline & $\begin{array}{c}\text { Measured } \\
\text { biomass }\end{array}$ & $\begin{array}{c}\text { Estimated } \\
\text { biomass }\end{array}$ & $\begin{array}{c}v \text {-value } \\
\left(\times 100 \mathrm{~cm}^{3}\right)\end{array}$ \\
\hline Koeleria cristata & 29.3 & 23.9 & 760 \\
\hline Agropyron cristatum & 19.3 & 21.0 & 416 \\
\hline Stipa baicalensis & 18.5 & 22.5 & 560 \\
\hline Caragana stenophylla & 15.4 & 13.4 & 84 \\
\hline Carex duriuscula & 14.3 & 8.9 & 33 \\
\hline Haplophyllum dahuricum & 7.1 & 11.0 & 51 \\
\hline Filifolium sibiricum & 3.8 & & \\
\hline Arenaria capillaris & 1.2 & 2.1 & 8 \\
\hline Allium bidentatum & 1.1 & 0.3 & 6 \\
\hline Serratula centauroides & 0.6 & 2.6 & 9 \\
\hline Potentilla bifurca & 0.5 & 0.0 & 4 \\
\hline Alyssum lenense & 0.4 & 0.0 & 4 \\
\hline Leymus chinensis & 0.3 & 5.1 & 15 \\
\hline Veronica incana & 0.3 & & \\
\hline Bupleurum scorzonerifolium & 0.3 & & \\
\hline Iris flavissima & 0.2 & & \\
\hline Medicago falcata & 0.1 & 0.7 & 6 \\
\hline Tragopogon trachycarpus & 0.1 & & \\
\hline Caragana pygmaea & & 5.8 & 17.5 \\
\hline Unidentified species & 1.0 & & \\
\hline Total $\left(\mathrm{g} \mathrm{m}^{-2}\right)$ & 113.8 & 117.3 & \\
\hline Litter $\left(\mathrm{g} \mathrm{m}^{-2}\right)$ & 221.9 & & \\
\hline Gross total $\left(\mathrm{g} \mathrm{m}^{-2}\right)$ & 335.7 & & \\
\hline$v$-value $\left(\times 100 \mathrm{~cm}^{3}\right)$ & & & 1972.50 \\
\hline
\end{tabular}


five quadrats varied from $97.6 \mathrm{~g} \mathrm{~m}^{-2}$ to $117.3 \mathrm{~g} \mathrm{~m}^{-2}$ (mean: standard error; $107.9 \pm 7.0 \mathrm{~g} \mathrm{~m}^{-2}$ ). In the grazed stand, the biomass weight varied from $60.7 \mathrm{~g} \mathrm{~m}^{-2}$ to $140.3 \mathrm{~g} \mathrm{~m}^{-2}\left(97.5 \pm 29 \mathrm{~g} \mathrm{~m}^{-2}\right)$. The result shows that the spatial distribution of the biomass in the grassland is heterogeneity. Given the need for the collection of multiple samples due to the natural heterogeneity of plant biomass, future studies of grassland biomass should increase the number of samples analyzed.

\section{Estimated Plant Biomass at Study Sites}

Using the equations given in Table 4 the plant biomasses in the

Table 4. Equations of relationship between the $v$-value $\left(\mathrm{cm}^{3}\right)$ and biomass (w:g) for the stands

\begin{tabular}{lllll}
\hline & \multicolumn{1}{c}{ Equations } & $R^{2}$ & $n$ & $p$ \\
\hline Baganule & & & & \\
Ungrazed & $\mathrm{w}=4.80 \ln (v)-7.90$ & 0.89 & 13 & $0.001^{*}$ \\
Grazed & $\mathrm{w}=0.15(v)^{0.88}$ & 0.82 & 16 & $0.001^{*}$ \\
\hline KBU & & & & \\
Ungrazed & $\mathrm{w}=0.90 \ln (v)-0.50$ & 0.55 & 8 & $0.05^{*}$ \\
Grazed & $\mathrm{w}=0.20 \ln (v)+0.92$ & 0.01 & 8 & $\mathrm{n} . \mathrm{s}^{*}$ \\
\hline Tumentsogt & & & & \\
Ungrazed & $\mathrm{w}=0.02 \mathrm{v}+1.18$ & 0.87 & 13 & $0.001^{*}$ \\
Grazed & $\mathrm{w}=3.25 \ln (v)-3.93$ & 0.76 & 11 & $0.001^{*}$ \\
\hline Hotont & & & & \\
Grazed & $\mathrm{w}=0.03 \mathrm{v}+1.66$ & 0.96 & 25 & $0.001^{*}$ \\
\hline
\end{tabular}

$\mathrm{n}$ : sample size.

Table 5. The measured and estimated plant biomasses in the stands

\begin{tabular}{lccc}
\hline \multirow{2}{*}{ Sites } & \multicolumn{3}{c}{ Plant biomass $\left(\mathrm{g} \mathrm{m}^{-2}\right)$} \\
\cline { 2 - 4 } & Measured (a) & Estimated (b) & $(\mathrm{a})-(\mathrm{b}) /(\mathrm{a})$ \\
\hline Baganuur & & & \\
Ungrazed & 113.8 & 108.0 & 0.05 \\
Grazed & 73.7 & 97.5 & -0.32 \\
\hline Tumentsogt & & & \\
Ungrazed & 83.5 & 70.3 & 0.16 \\
Grazed & 48.2 & 58.3 & -0.21 \\
\hline Hotont & & & 0.19 \\
Grazed & 143.4 & 116.7 & \\
\hline
\end{tabular}

study sits were estimated. Estimated plant biomass and measured plant litter are shown in Table 7. In Baganuur, the mean biomass produced in the 60 days from the beginning of the growing season in ungrazed and grazed stands were $107.9 \mathrm{~g} \mathrm{~m}^{-2}$ and $97.5 \mathrm{~g} \mathrm{~m}^{-2}$; the difference of $10.5 \mathrm{~g} \mathrm{~m}^{-2}$ was not significant by the MannWhitney $U$ test. The growth of plants in the grazed stand may be accelerated by grazing activity of livestock and also due to fertilization by excreta of the livestock. The mass of litter in the un-

Table 6. Variation of plant biomasses among five quadrats of the stands in Baganuur

\begin{tabular}{ccc}
\hline \multirow{2}{*}{ Sample number } & \multicolumn{2}{c}{ Plant biomass $\left(\mathrm{g} \mathrm{m}^{-2}\right)$} \\
\cline { 2 - 3 } & Ungrazed stand (a) & Grazed stand (b) \\
\hline 1 & 117.3 & 60.7 \\
2 & 113.0 & 71.0 \\
3 & 103.4 & 112.9 \\
4 & 108.4 & 140.3 \\
5 & 97.6 & 102.7 \\
\hline Mean \pm s.e. & $107.9 \pm 7$ & $97.5 \pm 29$ \\
\hline
\end{tabular}

s.e. : standard error.

Table 7. Estimated plant biomass and measured litter in the stands in Baganuur, KBU, Tumentsogt and Hotont

\begin{tabular}{lcc}
\hline \multicolumn{1}{c}{ Stands } & Mean biomass \pm s.e. $\left(\mathrm{g} \mathrm{m}^{-2}\right)$ & Litter $\left(\mathrm{g} \mathrm{m}^{-2}\right)$ \\
\hline Baganuur & & \\
Ungrazed (a) & $107.9 \pm 0.7$ & 221.9 \\
Grazed (b) & $97.5 \pm 28.8$ & 22.7 \\
(a)-(b) & 10.5 & 199.2 \\
\hline KBU & & \\
Ungrazed (a) & $13.4 \pm 2.2$ & 78.4 \\
Grazed (b) & $14.1^{\circ}$ & 27.8 \\
(a)-(b) & & 50.6 \\
\hline Tumentsogt & & \\
Ungrazed (a) & 72.6 & 330.3 \\
Grazed (b) & $58.6 \pm 4.0$ & 188.0 \\
(a)-(b) & 14.0 & 142.3 \\
\hline Hotont & 121.8 & 20.3 \\
Grazed & & \\
\hline
\end{tabular}

- Measured value. 
grazed and the grazed stands was $221.9 \mathrm{~g} \mathrm{~m}^{-2}$ and $22.7 \mathrm{~g} \mathrm{~m}^{-2}$, respectively, with the difference of $199.2 \mathrm{~g} \mathrm{~m}^{-2}$ considered to be that consumed by livestock. As shown in Table 7, plant and litter biomass in the ungrazed and grazed stands at Tumentsogt were 70.3 $\mathrm{g} \mathrm{m}^{-2}$ and $330.3 \mathrm{~g} \mathrm{~m}^{-2}$, and $58.2 \mathrm{~g} \mathrm{~m}^{-2}$ and $188.0 \mathrm{~g} \mathrm{~m}^{-2}$. Livestock grazed the aboveground plant litter as well as living plants. The difference of living plant biomass was not significant by the MannWhitney U test. In Tumentsogt, the amount of litter was $257.7 \mathrm{~g}$ $\mathrm{m}^{-2}$ more than the living plant biomass and the difference in plant litter the between ungrazed and grazed stands, considered reflect the amount grazed by livestock, was $142.3 \mathrm{~g} \mathrm{~m}^{-2}$. By way of comparison, the plant biomass and amount of litter in the grazed stand in Hotont were $115.8 \mathrm{~g} \mathrm{~m}^{-2}$ and $20.3 \mathrm{~g} \mathrm{~m}^{-2}$, respectively.

Estimation of Weight Ratio of above and below Ground Biomasses

The relationship between above-ground (Wa) and below ground $(\mathrm{Wb})$ weights in the plant of Artemisia scoparia is shown Fig. 2. The relationship is approximated as follows:

$$
\mathrm{Wb}=0.21 \mathrm{Wa}^{1.20}
$$

Using the equation, we are abele to estimate the below ground biomass from the above ground biomass of Artemisia scoparia.

\section{Carbon and Nitrogen Content of Plant and Litter}

Carbon and nitrogen content of plant material in grazed stand are given in Table 8. Mean carbon and nitrogen content in plants and litter was $43.0 \%$ and $1.9 \%$ and $33.7 \%$ and $1.4 \%$, respectively. In Baganuur, the amount of carbon in the aboveground plant biomass was $43.5 \mathrm{~g} \mathrm{C} \mathrm{m}^{-2}$ (435 $\mathrm{kg} \mathrm{C} \mathrm{ha}^{-1}$ ) (Table 9). Total carbon of the stand was $118.4 \mathrm{~g} \mathrm{C} \mathrm{m}^{-2}$, which included $74.9 \mathrm{~g} \mathrm{~m}^{-2}$ carbon in the litter. This implies that in early July $2005,1,184 \mathrm{~kg}$ of carbon per

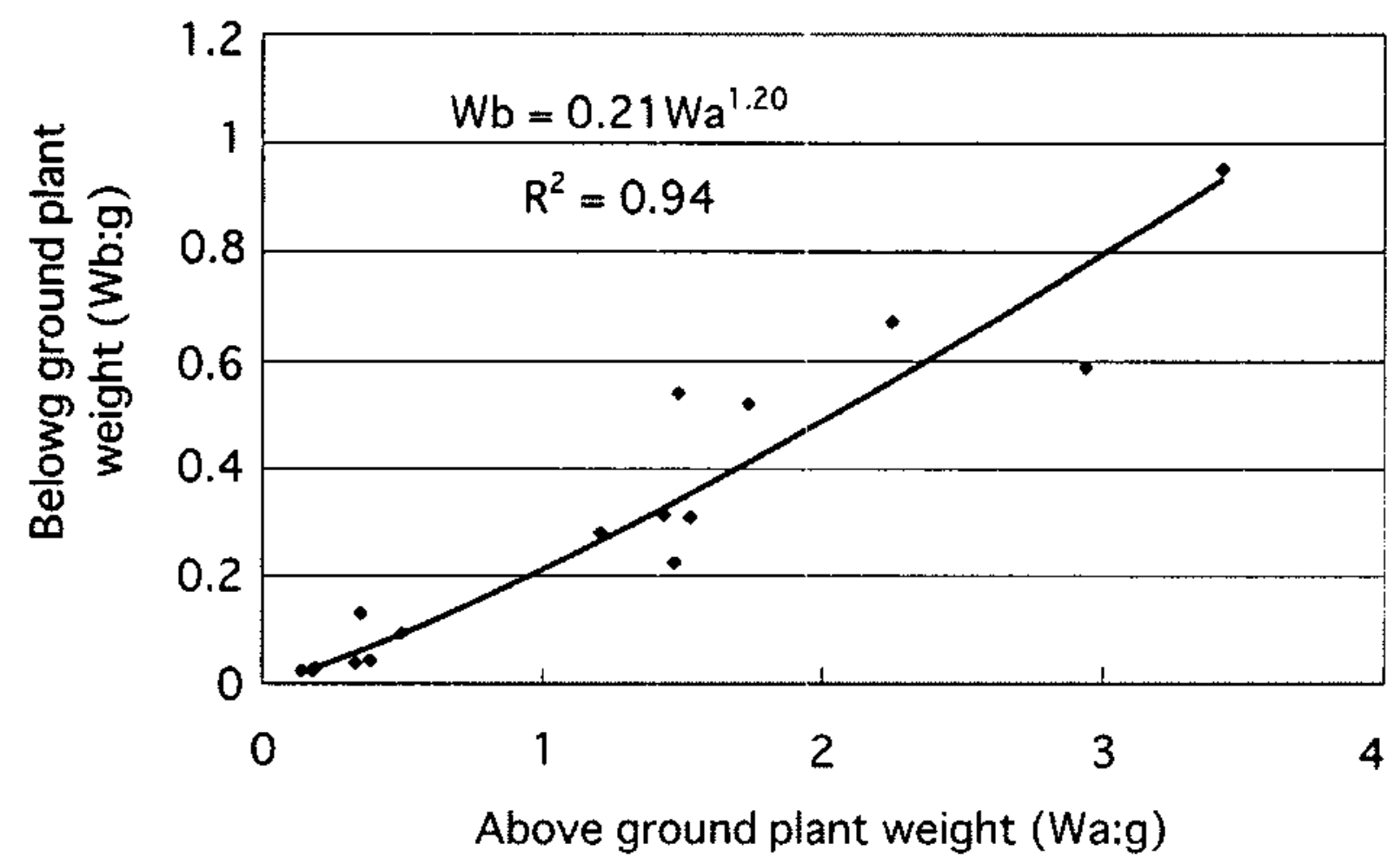

Fig. 2. Relationship between above (Wa) and below (Wb) ground plant weights of Artemisia scoparia.
Table 8. Carbon and nitrogen contents in plant materials collected from the Mongolian steppes. (s.e.: standard error)

\begin{tabular}{|c|c|c|c|c|}
\hline Species & Carbon (\%) & s.e. & Nitorogen $(\%)$ & s.e \\
\hline Agropyron cristatum $^{1)}$ & 41.2 & 3.8 & 1.5 & 0.1 \\
\hline Allium bidentatum ${ }^{2)}$ & 42.4 & 0.5 & 2.0 & 0.1 \\
\hline Artemisia glauca & 44.5 & 0.2 & 3.0 & 0.0 \\
\hline Carex duriuscula & 38.1 & 0.8 & 1.4 & 0.0 \\
\hline Carex duriuscula ${ }^{2)}$ & 43.3 & 0.1 & 1.9 & 0.0 \\
\hline Carex korshinskyi & 44.2 & 0.1 & 1.8 & 0.0 \\
\hline Koeleria cristata $^{1)}$ & 37.4 & 5.1 & 1.3 & 0.1 \\
\hline Koeleria cristata ${ }^{3)}$ & 43.8 & 0.1 & 1.8 & 0.0 \\
\hline Leymus chinensis ${ }^{3)}$ & 45.0 & 0.2 & 2.0 & 0.0 \\
\hline Stipa baicalensis ${ }^{1)}$ & 39.7 & 2.8 & 1.3 & 0.1 \\
\hline Stipa grandis $^{3)}$ & 44.8 & 1.6 & 1.7 & 0.3 \\
\hline Stipa krylovii ${ }^{2)}$ & 44.7 & 0.0 & 2.1 & 0.1 \\
\hline Stipa krylovii ${ }^{4}$ & 44.2 & 1.1 & 1.8 & 0.1 \\
\hline Achnatherum sibiricum ${ }^{3)}$ & 44.6 & 2.5 & 2.1 & 0.2 \\
\hline Other herb and grass ${ }^{1)}$ & 43.7 & 7.2 & 1.7 & 0.3 \\
\hline Other herb and grass ${ }^{4)}$ & 45.2 & 0.9 & 1.8 & 0.3 \\
\hline Other herb and grass ${ }^{3}$ & 44.0 & 0.1 & 1.9 & 0.1 \\
\hline Other herb and grass ${ }^{2)}$ & 42.4 & 1.2 & 2.2 & 0.1 \\
\hline Mean & 43.0 & 1.6 & 1.9 & 0.1 \\
\hline Litter $^{2)}$ & 33.7 & 2.1 & 1.4 & 0.0 \\
\hline
\end{tabular}

${ }^{1)}$ Baganuur, ${ }^{2)}$ Hotont, ${ }^{3)}$ Tumentsogt, ${ }^{4}$ Kherlenbayan-Ulaan.

hectare was held in the plant community as plant biomass and litter. The amount of carbon contained in plant biomass and litter were $31.2 \mathrm{~g} \mathrm{C} \mathrm{m}^{-2}$ and $111.4 \mathrm{~g} \mathrm{C} \mathrm{m}^{-2}$ in Tumentsogt and $51.1 \mathrm{~g} \mathrm{C} \mathrm{m}^{-2}$ and $6.8 \mathrm{~g} \mathrm{C} \mathrm{m}^{-2}$ in Hotont (Table 9). The nitrogen content of plant biomass and litter were $1.6 \mathrm{~g} \mathrm{~N} \mathrm{~m}^{-2}$ and $3.1 \mathrm{~g} \mathrm{~N} \mathrm{~m}^{-2}$ in the ungrazed stand in Baganuur (Table 9).

\section{DISCUSSION}

\section{Plant Biomass}

Variance in plant biomass among study stands was large because the spatial distribution of biomass in grassland was heterogeneous. We should, therefore, collect a number of quadrat samples to estimate the amount of biomass in grassland. We derived an equation to estimate the biomass without clipping of plants in the stand, because labor of clipping and identifying species is time consuming. 
Table 9. Carbon and nitrogen contents of plants and litter in the stands of the Mongolian steppes

\begin{tabular}{lccccc}
\hline \multirow{2}{*}{ Sites } & \multicolumn{2}{c}{ Carbon $\left(\mathrm{g} \mathrm{m}^{-2}\right)$} & & \multicolumn{2}{c}{ Nitorogen $\left(\mathrm{g} \mathrm{m}^{-2}\right)$} \\
\cline { 5 - 6 } Baganuur & Plants & Litter & & Plants & Litter \\
Ungrazed (a) & 43.5 & 74.9 & 1.6 & 3.1 \\
Grazed (b) & 39.6 & 7.7 & 1.4 & 0.3 \\
(a)-(b) & 3.9 & 67.2 & 0.1 & 2.8 \\
\hline KBU & & & & \\
Ungrazed (a) & 6.1 & 26.4 & 0.2 & 1.1 \\
Grazed (b) & 6.3 & 9.4 & 0.3 & 0.4 \\
(a)-(b) & -0.3 & 17.1 & 0.0 & 0.7 \\
\hline Tumentsogt & & & & \\
Ungrazed (a) & 31.2 & 111.4 & 1.3 & 4.6 \\
Grazed (b) & 25.9 & 63.4 & 1.1 & 2.6 \\
(a)-(b) & 5.3 & 48.0 & 0.2 & 2.0 \\
\hline Hotont & & & & \\
Grazed & 51.1 & 6.8 & 2.7 & 0.3 \\
\hline
\end{tabular}

Biomass production is affected by combined environmental factors such as meteorological factors, soils and human activities. Therefore, we are not able to consider the biomass production under separated situation.

The biomasses in the stands varied according to the precipitation and temperature not only among study sites but also between years. Nachinshonhor and Hirose (2002) reported that mean plant biomass was $127 \mathrm{~g} \mathrm{~m}^{-2}$ in an ungrazed stand in Tumentsogt in 1999 and 2001 , compared to our results of $70.3 \mathrm{~g} \mathrm{~m}^{-2}$ in the ungrazed stand in Tumentsogt in July 2005. This disparity is thought to be due to the difference in precipitation, with $280.4 \mathrm{~mm}$ occurring in 2005 and a mean value of $356.3 \mathrm{~mm}$ for 1999 and 2001 in Tumentsogt.

The difference of biomasses between the grazed and ungrazed stands, however, was not significant in statistical analysis (Table7). This suggests some accelerative effects of livestock activity to plant growth in the grazed stand.

In this study the plant biomass was assessed in early July, the time of harvest before the date the maximum biomass occurred in the growing season (biomass at harvest time). The plant biomass continues to increase until late August and is decomposed by soil microorganism after withering. The Mongolian steppe environment was found to have a large amount of plant litter. The litter consisted primarily of withered plants from the current growing season and organic residual litter from the previous year, as well as withered roots and rhizomes, all of which contribute to the organic content of the soil.

Numerous studies have been conducted on plant biomass in the Inner Mongolian and Mongolian steppes (Davazamc 1985, Jiang et al. 1985, Hayashi et al. 1988, Kawamura et al. 2003, Kawamura et al. 2005, Bai et al. 2007). Yiruhan et al. (2001) reported that the average aboveground plant biomass at 23 sites was $198 \mathrm{~g} \mathrm{~m}^{-2}$ with standard deviation of $68 \mathrm{~g} \mathrm{~m}^{-2}$ in the Inner Mongolian grasslands. While Kawamura et al. (2005) obtained plant biomass values of $134.5 \mathrm{~g} \mathrm{~m}^{-2}$ with standard deviation of $75.1 \mathrm{~g} \mathrm{~m}^{-2}$ in the same region using a remote sensing method. Mean plant biomass in the steppe regions of Mongolia and Inner Mongolia appear to be between circa $100 \mathrm{~g} \mathrm{~m}^{-2}$ and $200 \mathrm{~g} \mathrm{~m}^{-2}$ ( 1 and 2 tons per hectare). Using the eddy covariance method, Kato et al. (2004) reported that the net ecosystem production (NEP) was $153.1 \mathrm{~g} \mathrm{~m}^{-2}$ in a growing season in the Qinghai-Tibetan Plateau, China. The value given by Kato et al. (2004) is equivalent to approximately $356.0 \mathrm{~g} \mathrm{~m}^{-2}$ of biomass including below ground biomass.

The total plant biomass in a stand is taken as the aboveground biomass plus the belowground biomass (roots and rhizomes). The amount of belowground plant biomass in a stand has been observed to vary between studies, because the measurement techniques employed to assess belowground biomass differed between studies. For example, according to Jiang et al. (1985), above- and belowground biomasses per square meter of Stipa grandis were $125.5 \mathrm{~g}$ and 345.8 g. Similarly, for Aneulorepidium chinense (Leymus chinensis) these values were $142.0 \mathrm{~g}$ and $616.1 \mathrm{~g}$, respectively. In the same study $_{2}$ the ratios of aboveground biomass to belowground biomass were 2.76 and 4.34, respectively. Hayashi et al. (1988) reported the relationship between aboveground biomass $(\mathrm{T}: \mathrm{g})$ and belowground biomass (R: $\mathrm{g}$ ) using the data of $\mathrm{Li}$ et al. (1988) in a stand in Inner Mongolia as: $R=113.3 \exp (0.0076 \mathrm{~T})$. However, the measured belowground biomass of Jiang et al. (1985) was larger than that predicted by the equation. Davazamc (1985) reported that the belowground plant biomass of Stipa krylovii stand in Mongolia was 2,500 $\mathrm{g} \mathrm{m}^{-2}$, which was 23 times larger than that of the aboveground biomass.

According to Fig. 2, the weight ratio of the below ground to above ground was estimated 2.9 for Artemisa scoparia with plant weight of $200 \mathrm{~g}$. In present study, by adopting the ratio of 2.76 of Jiang et al. (1985), the estimated belowground biomass in the ungrazed stand in Baganuur was $257.5 \mathrm{~g} \mathrm{~m}^{-2}$, while the total plant biomass in the ungrazed and grazed stands was $365.5 \mathrm{~g} \mathrm{~m}^{-2}$ and $335.2 \mathrm{~g} \mathrm{~m}^{-2}$ in Baganuur on 30 June 2005. In the mature stand in a steady state, the belowground biomass produced in a growing season is totally decomposed during the subsequent fall and winter 
after withering. If the roots and rhizomes survive in this period, the belowground biomass continues to increase and occupies the belowground space with roots and rhizomes for several years. The rest of the biomass is retained in the soil as organic matter during the fall and winter. In Mongolia, withered roots, rhizomes and litter are thought to constitute a major component of soil organic matter because decomposition is limited by low temperature and arid climate.

\section{Amount of Carbon and Nitrogen in the Stands}

The carbon in plant biomass and plant litter were sequestrated from the atmosphere during growing season in this study sites. This carbon contained within the plant material contributes to the carbon sink of the grassland ecosystem. The amount of carbon in the plants of the ungrazed grasslands in Baganuur, KBU and Tumentsogt was $435 \mathrm{~kg} \mathrm{ha}^{-1}, 61 \mathrm{~kg} \mathrm{ha}^{-1}$ and $312 \mathrm{~kg} \mathrm{ha}^{-1}$ in early July 2005 , respectively (Table 9). In the grazed stands, the amount of carbon was $396 \mathrm{~kg} \mathrm{ha}^{-1}$ in Baganuur, $63 \mathrm{~kg} \mathrm{ha}^{-1}$ in KBU and $259 \mathrm{~kg} \mathrm{ha}^{-1}$ in Tumentsogt. Approximately $90 \%$ percent of the carbon in this aboveground plant biomass would have been accumulated in the 60-day growing season if plant was considered to start on 1 May in the year of the study. Approximately $10 \%$ of the carbon supplies from storage organs are produced in the preceding growing season (Hayashi 2003). The carbon contained in the plant litter of ungrazed and grazed stands in Baganuur was $749 \mathrm{~kg} \mathrm{ha}^{-2}$ and $77 \mathrm{~kg} \mathrm{ha}^{-2}$, respectively. Almost all of the carbon in the litter was sequestrated from atmosphere in the preceding year.

Chen et al. (1985) reported that the nitrogen content of Artemisia frigida, Stipa grandis and Stipa baicalensis in Inner Mongolian grasslands was $2.7 \%, 1.6 \%$ and $1.3 \%$, respectively, which is similar to the findings presented in this study. We were able to determine the amount of nitrogen in a plant community by converting the nitrogen content for each species to the plant biomass in the stand. For example, in the ungrazed stand in Baganuur, the plant community contained $1.6 \mathrm{~g} \mathrm{~m}^{-2}$ of nitrogen (Table 9). Some of the nitrogen contained in these plants is transferred to livestock, making the nitrogen dynamics in the ecosystems of this region. The grassland ecosystems in Mongolia are thus important for the raising of livestock and the conservation of environments, including the sequestration of the atmospheric carbon.

Numerous biomass or carbon budget measurements have been undertaken in ecosystems using physical methods such as remote sensing and the eddy covariance methods (Kawamura et al. 2003, Kato et al. 2004). However, although these techniques can be used to generate much physical data and characterize the carbon budgets of these ecosystems, they cannot be employed to restore damaged ecosystems. Conversely, ecological approach, such as that on the floristic composition shown in Table 3, can be used to restore damaged ecosystems. Because, we can rehabilitate the damaged stand using suitable plant species with information on floristic composition of the stands, which indicates the stand characteristics such as temperature, precipitation and soil properties (Hayashi 1996). Since plant succession can be used to predict changes in species and biomass dynamics in the stands subjected to grazing (Wang 1992, Wuyunna et al. 1999, Nakamura et al. 2000, Hayashi 2003, Kawada et al. 2006, Cheng and Nakamura 2007), then it is likely that the theory can be applied to determining which species are well suited for use in rehabilitation or to restore degraded grasslands.

\section{ACKNOWLEDGEMENTS}

We devote much thanks to Dr L. Targalsaikhan, Institute of Botany, Mongolian Academy of Science, Ulaanbaatar, Mongolia for his allowance to use the experimental station.

\section{LITERATURE CITED}

Bai Y, Wu J, Pan Q, Huang J, Wang Q, Li F, Buyantuyev A, Han X. 2007. Positive linear relationship between productivity and diversity: evidence from the Eurasian Steppe. J Appl Ecol 44: 10231034.

Chen Z, Huang D, Zhang H. 1985. The characteristics of element chemistry of 122 plants on the Xilin river valley, Inner Mongolia. Research on Grassland Ecosystem 1: 112-131 (in Chinese with English summary).

Cheng Y, Nakamura T. 2006 Phytosociological study on steppe vegetation in the vicinity of Kharkiv, Ukraine. Grassl Sci 52: 61-71.

Cheng Y, Nakamura T. 2007. Phytosociological study on steppe vegetation in east Kazakhstan. Grassl Sci 53: 172-180.

Davâzamc C. 1985. Dynamik der Produktivität der unterirdischen Phytomase der Vegetationszonen der MVR. Arch. Naturschutz u. Landschaftsforsh 25: 3-11.

Gunin PD, Vostokova EA, Dorofeyuk NI, Tarasov PR, Black CC. (eds). 1999. Vegetation Dynamics of Mongolia. Kluwer Academic Publication, Netherland, 1-238.

Hayashi I. 1996. Five years experiment on vegetation recovery of drought deciduous woodland in Kitui, Kenya. J Arid Environ 34: 351-361.

Hayashi I. 2003. Plant ecology: Principals and Applications. Kokonshoin, Tokyo (in Japanese).

Hayashi I, Jiang S, Nakamura T. 1988. Phytomass production of grasslands in Xilin River Basin, Xilingol, Inner Mongolia, China. Bull. Sugadaira Montane. Res Cen 9: 13-31.

Hiblig W, Opp C. 2005. The effects of anthropogenic impact on plant and soil cover in Mongolia. Erforsh Boil Ress Mongolia 9: 1693177.

Institute of Meteorology and Hydrology of Mongolia. 2005. Meteorological Records in Mongolia. Ulaanbaatl.

Jiang S, Qi Q, Kong D. 1985. A comparative study on production of Aneurolepidium chinense and Stipa grandis steppe communities at 
Baiinxile livestock farm in Inner Mongolia region. Research on Grassland Ecosystem 1: 12-23 (in Chinese).

Kato T, Tang Y, Gu S, Cui X, Hirota M, Du M, Li Y, Zhao X, Oikawa T. 2004. Carbon dioxide exchange between the atmosphere and alpine meadow ecosystem on the Quinghai-Tibetan Plateau, China. Agric For Meteorol 124: 121-134.

Kawada K, Alexandra GV, Filatova, OV, Araki M, Nakamura T, Hayashi I. 2006. Floristic composition and plant biomass production of steppe communities in the vicinity of Kharkiv, Ukraine. Grassl Sci 51: 205-213.

Kawamura K, Akiyama T, Watanabe O, Hasegawa H, Zhang FP, Yokota H, Wang S. 2003. Estimation of aboveground biomass in Xilingole steppe, Inner Mongolia Using NOAA/NDVI. Grassl Sci 46: $1-9$.

Kawamura K, Akiyama T, Yokota H, Tsutsumi M, Yasuda T, Watanabe $\mathrm{O}$, Wang S. 2005. Comparing MODIS vegetation indices with AVHRR NDVI for monitoring the forage quantity and quality in Inner Mongolian grassland, China. Grassl Sci 51: 33-40.

Li B, Shipeng Y, Li Z. 1988. The vegetation of the Xilin River Basin and its utilization. Research on Grassland Ecosystem 3:84-183 (in Chinese).

Nachinshonhor GU, Hirose T. 2002. Productivity of Mongolian grassland and nomadism. Papers on Mongolian Studies in a series of Northeast Asian Studies 6: 59-67 (in Japanese).
Nakamura T, Go T, Wuyunna, Hayashi I. 2000. Effect on grazing on the floristic composition of grassland in Bayinxile, Xilingole, Inner Mongolia. Grassl Sci 45:342-350.

Numata M. 1987. Structure of plant community. In: Theoretical consideration on plant ecology. Tokaidaigaku-shuppankai, Tokyo, 51263 (in Japanese).

Sasaki T, Okayasu T, Takeuchi K, Jamsran U, Jadambaa S. 2005. Pattern of floristic composition under different grazing intensities in Bulgan, South Gobi, Mongolia. Grassl Sci 51: 235-247.

Wang Y. 1992. Vegetation dynamics of grazing succession in the Stipa baicalensis steppe in Northeastern China. Vegetatio 98: 83-95.

Wuyunna, Nakamura T, Hayashi I. 1999. Species diversity and phytomass of the grasslands in Inner Mongolia, China. Grassl Sci 45: 140-148 (in Japanese).

Wuyunna, Okamoto K. 2004. Degeneration of steppe vegetation and the sandy desertification in Inner Mongolia, China. Vegetation Science News 8: 17-25 (In Japanese).

Xie Y, Becker U, Witting R. 2007. Vegetation of the Stipa loess steppe in Ningxia (northern China) in relation to grazing intensity. Grassl Sci 53: 143-145.

Yiruhan, Hayashi I, Nakamura T, Shiomi M. 2001. Changes in floristic composition of grasslands according to grazing intensity in Inner Mongolia, China. Grassl Sci 47: 362- 369.

(Received March 7, 2008; Accepted May 14, 2008) 